\title{
Comparative Phytochemical and Proximate Compositions of Cola acuminata (P. Beauv.) Schott and Cola nitida (Vent) Schott and Endl.
}

\author{
Okeke, Clement Uwabunkeonye ${ }^{1}$, Chinelo Anthonia Ezeabara ${ }^{1, ~}$, Chimezie, Horoiheoma ${ }^{2}$, \\ Udechukwu, Chidozie Denis ${ }^{1}$, Bibian Okwuchukwu Aziagba ${ }^{1}$ \\ ${ }^{1}$ Department of Botany, Nnamdi Azikiwe University, Awka, Anambra State, Nigeria \\ ${ }^{2}$ Department of Plant Science and Biotechnology, Abia State University, Uturu, Abia State, Nigeria
}

Email address:

Clementuokeke@yahoo.com (C. U. Okeke), e.chinelo5@yahoo.com (C. A. Ezeabara)

To cite this article:

Okeke, Clement Uwabunkeonye, Chinelo Anthonia Ezeabara, Chimezie, Horoiheoma, Udechukwu, Chidozie Denis, Bibian Okwuchukwu Aziagba. Comparative Phytochemical and Proximate Compositions of Cola acuminata (P. Beauv.) Schott and Cola nitida (Vent) Schott and Endl.. Plant. Vol. 3, No. 3, 2015, pp. 26-29. doi: 10.11648/j.plant.20150303.12

\begin{abstract}
Seeds, leaves and stems of Cola acuminata (P. Beauv.) Schott and Cola nitida (Vent) Schott and Endl. Were ovendried at $60^{\circ} \mathrm{C}$ for 24 hours and standard analytical laboratory methods were used for proximate and phytochemical tests. Sterols and triterpenes were absent in all the parts of the two species. Starch was absent in the leaves of Cola acuminata and C. nitida. Trace amount of hydrogen cyanide was only detected in the seed of C. acuminata. Alkaloid, flavonoid, saponin, tannin as well as high level of protein and minerals were found in all the parts of the two species in varying concentrations. Seed of $C$. acuminata has higher alkaloid content $(0.26 \pm 0.11 \%)$ and as a result could have a higher stimulating property. These chemical characters could be considered as additional characters in delimitation of the two species as well as proper placement of the family, Sterculiaceae.
\end{abstract}

Keywords: Alkaloid, Chemical characters, Cola acuminata, Cola nitida, Kola nut, Sterculiaceae

\section{Introduction}

Sterculiaceae family is predominant in both tropical and subtropical countries, and composed of about 60 genera and 700 species. In West Africa alone, there are 17 genera and 83 species, half of which are Cola species [1]. Hutchinson placed Sterculiaceae under the order Tiliales, but Bentham and Hooker, Engler and Prantl, Takhtajan, Cronquist and Thorne placed it under Malvales. The family differs from both Malvaceae and Tiliaceae families based on the absence of definite number of stamens. Even though, Sterculiaceae is regarded as having derived from the stock as Tiliaceae, it showed close affinities with Euphorbiaceae by showing the presence of stellate hairs, tendency to unisexuality and arils in the seeds [2].

Kola plant is a native of Africa. There are about 125 species of the plant, all of which are indigenous to Tropical West Africa [3,4]. Cola acuminata originated from Congo, Southern Nigeria, Togo, Gabon and Angola [3,5]. Cola nitida, on the other hand, originated from forest zones of Sierra
Leone, Ivory Coast and Ghana. Since, 1912, it has been planted extensively in Western Nigeria, and was taken to Jamaica and Brazil by slaves around 1930.The plants distributed by Kew to various tropical botanic gardens in 1880's under the name of Cola acuminata was said to have been Cola nitida [3].

Cola nitida has only two cotyledons, while Cola acuminata has more than two cotyledons. Other morphological differences between the two species have been described [6,3,5]. Three subspecies (alba, ballayi and astrophora) in Cola acuminata and one subspecies (vera) in Cola nitida was reported by Ghani [7], while [3] recognized albida as a subspecies of Cola nitida.

Kola nut is edible, with tremendous medicinal, religious and social values in Nigeria. The economic values and reactions in the body have been discussed extensively by various workers $[3,5,7,8,9]$. Comparative nutritional and chemical contents of the two species are therefore required, 
as additional characters in delineating them. This may also furnish additional information that may be helpful in resolving the on-going controversy involved in the placement of the Sterculiaceae in the right order.

\section{Materials and Methods}

\subsection{Plant Materials}

The fruit, leaf and stem samples of both Cola acuminata and $C$. nitida used for this study were obtained from the premises of the National Root Crop Research Institute, Umudike, Abia State, Nigeria. The Voucher specimens were deposited in the Herbarium of Abia State University, Uturu, Nigeria.

\subsection{Preparation of Plant Materials}

Two hundred gram (200g) of the seed, leaf and stem samples used were oven-dried at $60^{\circ} \mathrm{C}$ for 24 hours.

\subsubsection{Preliminary Phytochemical Tests}

The preliminary phytochemical tests for the presence or absence of alkaloid, saponin, flavonoid, sterols and triterpenes, tannins, glycoside and starch were carried out following standard methods of Beckett and Stenlake [10]. The symbol '+' denoted presence while '-' indicated absence.

\subsubsection{Quantitative Phytochemical Tests}

The quantitative phytochemical tests were conducted using a standard method [11].

\subsubsection{Proximate Analyses}

Proximate analyses of the test samples were conducted following the standard methods of Ene-Obong and Carnovale [12].

\subsubsection{Statistical Analysis}

Data were presented as mean $\_$Standard deviation of triplicate determinations.

\section{Results}

The results of the phytochemical and proximate studies were shown in Tables 1-3.Sterols and triterpenes were absent in all the parts of the two species. Starch was absent in the seeds and leaves of Cola acuminata as well as in the leaves of Cola nitida. Philoba-tannin was present in the leaves but absent in the stems of both Cola acuminata and C. nitida. Hydrogen cyanide was absent in all the parts of the two species except in the seeds of Cola acuminata (Table 1).

Alkaloid, flavonoid, saponin and tannin were present in all the parts of the two species (Tables 1 and 2). Alkaloid level of seeds $(0.26 \pm 0.11 \%)$ and leaves $(0.16 \pm 0.1 \%)$ of Cola acuminata were higher. Highest concentration of saponin was found in the leaves $(0.24 \pm 0.2 \%)$ of Cola nitida. High flavonoid content was contained in the leaves $(0.24 \pm 0.2 \%)$ of Cola acuminata as well as seeds $(0.24 \pm 0.2 \%)$ and leaves
$(0.26 \pm 0.1 \%)$ of $C$. nitida. Tannin content was greatest in the leaves $(0.32 \pm 0.1 \%)$ of $C$. acuminata (Table 2$)$.

High levels of protein were present in the seeds and leaves of both species with higher concentrations in those of Cola acuminata. Carbohydrate and potassium contents of the two species were higher in the seeds and leaves. Fibre and calcium values were higher in the stems of the two plants. Highest levels of phosphorus and sodium were detected in the leaves of the plants followed by the seeds with least in the stems. High levels of magnesium were found in the leaves of Cola acuminata $(72.00 \pm 1.2 \%)$ as well as in the leaves $(78.00 \pm 1.3 \%)$ and seeds $(58.18 \pm 1.7 \%)$ of C. nitida (Table 3).

\section{Discussion}

The result showed that Cola acuminata and C. nitida contained rich bioactive compounds and nutrients; with carbohydrate, protein and minerals in high concentrations as well as a trace of hydrogen cyanide detected in seed of $C$. acuminata only. The seeds of both species are edible. Cola acuminata has a very high cultural value in Southeastern Nigeria. They are used in every traditional rituals and ceremonies. Cola nitida seeds, on the other hand, are predominantly taken by the Northerners.

Alkaloids were higher in the seeds and least in the stems of the two plants and this tallied with [13] finding. He reported that the nuts of $C$. nitida grown in Ghana contained more caffeine. Caffeine is well known alkaloids of plant origin. Most of the physiological actions of $C$. nitida have been found to be due to caffeine content [14]. Caffeine has been reported to be among the social drugs consumed by humans [15]; which is as a result of its stimulating effect, presumably. Caffeine has also been known as fat burner and is beneficial in assisting weight loss [16,17]. In addition, glucose lowering effect of $C$. acuminata has been observed [18]; suggesting that it has an antidiabetic effect. Meanwhile, this could be as a result of alkaloid content of the plant. Alkaloids have been reported to possess an antidiabetic effect [19].

Furthermore, percentage phenol in the seeds and stems of the two species were relatively the same whereas the stems contained the least value. However, higher value of phenol was found in the leaves of $C$. nitida. This agreed with the observation of Lee and Jaworski [20], who stated that the percentage phenol in $C$. nitida was higher.

Hydrogen cyanide was only present in the seeds of $C$. acuminata in trace quantity. In a previous study, it was reported that kola nut could mimic malaria-like symptoms in the body when taken at a high concentration (about $35 \mathrm{~g} /$ day), stating that this quantity would leave a high level of caffeine and cyanide in the circulation so that people with a low level of malaria parasite in them would notice active infection which otherwise may have been controlled by the host immune system [21]. This observation could be applicable to the seed of C. acuminata because of its higher alkaloid value and presence of trace amount of hydrogen cyanide; but not $C$. nitida. 
Table 1. Qualitative phytochemical compositions of Cola acuminata and C. nitida.

\begin{tabular}{lllllll}
\hline Compositions & Cola acuminata & & & Cola nitida & & \\
\hline & Seeds & Leaves & Stems & Seeds & Leaves & Stems \\
\hline Alkaloid & + & + & + & + & + & + \\
Saponin & + & + & + & + & + & + \\
Flavonoid & + & + & - & + & + & + \\
Sterols and triterpenes & - & - & + & + & + & + \\
Tannins & + & + & - & + & + & - \\
Philoba-tannin & + & + & - & + & - & + \\
HCN & + & - & + & & - & + \\
Starch & - & - & & & & + \\
\hline
\end{tabular}

$(+)=$ present; $(-)=$ absent. $\mathrm{HCN}=$ Hydrogen cyanide

Table 2. Quantitative phytochemical compositions of Cola acuminata and C. nitida (\%).

\begin{tabular}{lllllll}
\hline \multirow{2}{*}{ Constituents } & Cola acuminata & & \multicolumn{3}{c}{ Cola nitida } \\
\cline { 2 - 7 } & Seeds & Leaves & Stems & Seeds & Leaves & Stems \\
\hline Alkaloid & $0.26 \pm 0.11$ & $0.16 \pm 0.1$ & $0.08 \pm 0.01$ & $0.22 \pm 0.1$ & $0.14 \pm 0.1$ & $0.08 \pm 0.01$ \\
Saponin & $0.12 \pm 0.12$ & $0.18 \pm 0.1$ & $0.12 \pm 0.02$ & $0.18 \pm 0.02$ & $0.24 \pm 0.2$ & $0.12 \pm 0.1$ \\
Flavonoid & $0.18 \pm 0.1$ & $0.24 \pm 0.2$ & $0.08 \pm 0.01$ & $0.24 \pm 0.1$ & $0.26 \pm 0.1$ & $0.06 \pm 0.01$ \\
Phenol & $0.28 \pm 0.2$ & $0.26 \pm 0.11$ & $0.12 \pm 0.1$ & $0.28 \pm 0.03$ & $0.28 \pm 0.03$ & $0.12 \pm 0.1$ \\
Tannin & $0.28 \pm 0.13$ & $0.32 \pm 0.1$ & $0.14 \pm 0.02$ & $0.26 \pm 0.11$ & $0.26 \pm 0.11$ & $0.14 \pm 0.1$ \\
\hline
\end{tabular}

Data are mean $\_$standard deviation of triplicate determinations

Table 3. Quantitative proximate composition of Cola acuminata and Cola nitida (\%).

\begin{tabular}{lllllll}
\hline \multirow{2}{*}{ Constituents } & \multicolumn{1}{l}{ Cola acuminata } & \multicolumn{5}{l}{ Cola nitida } \\
\cline { 2 - 7 } & Seeds & Leaves & Stems & Seeds & Leaves & Stems \\
\hline Protein & $9.10 \pm 0.12$ & $10.15 \pm 1.1$ & $1.40 \pm 0.01$ & $8.58 \pm 1.1$ & $7.35 \pm 0.1$ & $1.40 \pm 0.1$ \\
Fat & $2.16 \pm 0.01$ & $2.04 \pm 0.1$ & $0.36 \pm 0.2$ & $2.24 \pm 0.1$ & $2.10 \pm 0.01$ & $0.42 \pm 0.2$ \\
Fibre & $3.22 \pm 0.1$ & $18.64 \pm 0.2$ & $66.98 \pm 1.1$ & $2.46 \pm 0.2$ & $19.28 \pm 1.1$ & $66.82 \pm 1.3$ \\
Ash & $6.48 \pm 0.2$ & $5.88 \pm 0.1$ & $4.34 \pm 2.1$ & $5.64 \pm 0.3$ & $5.64 \pm 0.2$ & $4.28 \pm 0.1$ \\
NFE(CHO) & $79.02 \pm 1.1$ & $63.29 \pm 0.1$ & $26.94 \pm 1.3$ & $80.90 \pm 2.1$ & $66.23 \pm 1.6$ & $27.08 \pm 1.1$ \\
Ca & $20.64 \pm 1.2$ & $22.80 \pm 1.1$ & $134.60 \pm 1.5$ & $28.60 \pm 1.2$ & $24.60 \pm 0.7$ & $132.80 \pm 1.3$ \\
Mg & $44.80 \pm 1.1$ & $72.00 \pm 1.2$ & $18.00 \pm 0.1$ & $58.18 \pm 1.7$ & $78.00 \pm 1.3$ & $16.00 \pm 1.1$ \\
K & $266.40 \pm 2.1$ & $284.00 \pm 2.0$ & $156.00 \pm 1.3$ & $248.40 \pm 2.3$ & $288.00 \pm 1.8$ & $196.00 \pm 1.2$ \\
$\mathrm{Na}$ & $52.14 \pm 0.3$ & $76.00 \pm 1.2$ & $22.00 \pm 1.1$ & $46.72 \pm 1.6$ & $72.00 \pm 0.7$ & $18.00 \pm 1.1$ \\
$\mathrm{P}$ & $194.00 \pm 0.3$ & $244.00 \pm 2.0$ & $66.00 \pm 0.7$ & $182.00 \pm 3.1$ & $246.00 \pm 3.1$ & $68.00 \pm 0.6$ \\
\hline
\end{tabular}

Data are mean $\underline{+}$ standard deviation of triplicate determinations

\section{Conclusion}

It is clear that the slight differences in the chemical characters of the two species suggested a close affinity. However, the stimulating property of seeds of Cola acuminata would probably be higher than that of $C$. nitida, due to higher alkaloid content. The absence of starch and presence of hydrogen cyanide in the seeds of Cola acuminata and vice versa could be used as additional characters for delineating between the two species.

In addition, seeds, leaves and stem of the two plants have high protein and mineral contents and therefore, could be regarded nutritious; but moderate intake may be beneficial.

\section{References}

[1] L.S. Gill, Ethnobotanical Uses of Plants, 1st ed. Uniben Press, Benin. 1992; pp. 161.

[2] O.P. Sharma, Plant Taxonomy, 1st ed. Tata McGraw-Hill Publishing Company Ltd., New Delhi.1993; pp. 482.

[3] J.W. Purseglove, Tropical Crops: Dicotelydons. Vol. 163.Wiley, New York.1969; pp. 3871.

[4] A.C. Dutta, Botany for Degree Students, 5th ed. Oxford University Press, New Delhi. 1981; pp. 825. 
[5] T.E. Wallis, Textbook of Pharmacognosy, 5th ed. CBS, Publishers, India.1985; pp. 652.

[6] R.W. Keay, C.F.A. Onochie, D.P. Stanfield, Nigerian Trees Vol 2. Federal Department of Forest Research, Ibadan.1964; pp. 329.

[7] D.P. Ghani, A. Introduction to Pharmacognosy. ABU Press Ltd., Zaria. 1990; pp. 250.

[8] I. Etukudo, Forests our Divine Favour. Dorand Publishers, Uyo.2000; pp. 194.

[9] I. Etukudo, Ethnobotany: Conventional and Traditional uses of Plants, 1st ed. The Verdict Press, Uyo. 2003; pp. 191.

[10] A.H. Beckett, J.B. Stenlake, Practical Pharmaceutical Chemistry: Part 1.Continuum International Publishing Group Ltd., London. 1988; pp. 235.

[11] J.B. Harborne, Phytochemical Methods, 1st ed. Chapman and Hall, London.1973; pp. 273.

[12] H.M. Ene-Obong, E. Carnovale, A comparison of the proximate, mineral and amino acid composition of some known and lesser-known legumes in Nigeria. Food Chemi., 1992; 43:169-175.

[13] F.R. Irvine, Woody Plants of Ghana: with Special Reference to their Uses. Oxford University Press, London. 1961; pp. 868.
[14] C.L.M. Eijnatten, Kola: A Review of the Literature. Tropical Abstracts, 1973; 28:541-550.

[15] M.H. Zenk, M. Juenger, Evolution and current status of the phytochemistry of nitrogenous compounds. Phytochem., 2007; 68: $2757-72$.

[16] M. Blades, Functional Foods. Neutraceut. Nutri. Food Sci., 2000; 30(2):73-75.

[17] E.A. Alagwu, E.E. Osim, C.M. Nwozor, O.T. Edom, Effects of aqueous kola nut (Cola nitida) extracts on the contraction of isolated rabbit ileum. J. Sci. Multidisciplinary Res., 2014; 6(1):82-89.

[18] F. Adediwura, N. Bernard, A. Omotola, Biochemical effects of chronic administration of Cola acuminata (P. Beauv.) Schott and Endl. extracts in alloxan induced diabetic rats. Asian J. Pharmaceut. Biol. Res., 2011; 1(3): 355-359.

[19] K.O. Soetan, O.O. Aiyelaagbe, The need for bioactivity-safety evaluation and conservation of medicinal plant- A review. J. Med. Plant Res., 2009; 35: 324-328.

[20] C.Y. Lee, A. Jaworski, Phenolic compounds in white grape grown in New York. Am. Enol. Viticul., 1987; 38:277-281.

[21] A.A.A. Alaibe, G.C. Ejezie, E.N.U. Ezedinachi, The role of cola nut (Cola nitida) in the etiology of malaria morbility. Pharmaceut. Biol., 2003; 41(6):458-462. 